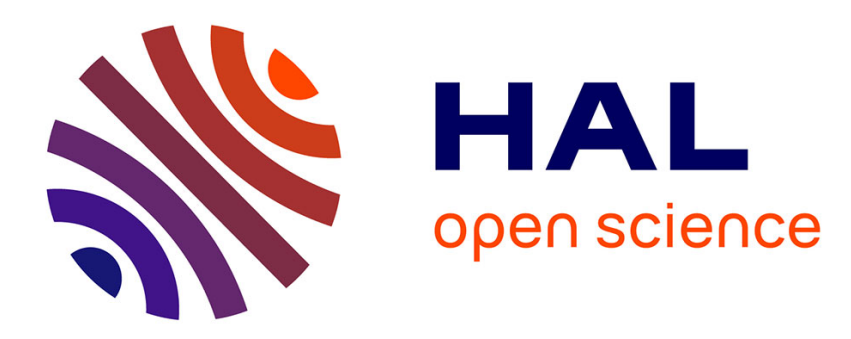

\title{
Development in aquatic humic chemistry
}

Fritz Frimmel

\section{To cite this version:}

Fritz Frimmel. Development in aquatic humic chemistry. Agronomie, 2000, 20 (5), pp.451-463. 10.1051/agro:2000141 . hal-00886066

\section{HAL Id: hal-00886066 https://hal.science/hal-00886066}

Submitted on 1 Jan 2000

HAL is a multi-disciplinary open access archive for the deposit and dissemination of scientific research documents, whether they are published or not. The documents may come from teaching and research institutions in France or abroad, or from public or private research centers.
L'archive ouverte pluridisciplinaire HAL, est destinée au dépôt et à la diffusion de documents scientifiques de niveau recherche, publiés ou non, émanant des établissements d'enseignement et de recherche français ou étrangers, des laboratoires publics ou privés. 
Review article

\title{
Development in aquatic humic chemistry
}

\author{
Fritz Hartmann FRIMMEL \\ Chair for Water chemistry, Universitaet Karlsruhe, Engler-Bunte-Ring 1, 76131 Karlsruhe, Germany
}

(Received 29 September 1999; revised 11 May 2000; accepted 16 May 2000)

\begin{abstract}
There are always specific achievements which affect scientific work. This also applies to the field of aquatic humic chemistry. Some of the milestones were: (1) the standardization of isolation procedures for humic substances and by this the availability of reference materials; (2) the application of powerful tools of NMR spectroscopy and mass spectroscopy in combination with pyrolysis for the identification of molecular building blocks; (3) the application of gel chromatography with multidetection, including vibrational and electronic spectroscopy and on-line measurement for direct characterisation of organic matter in aquatic samples; (4) the application of static and time-resolved fluorescence to study excited states and complex formation; (5) the investigation of reactions with well defined partners; and (6) the development of computer models for energy minimized molecular structures.
\end{abstract}

\section{isolation procedure / spectroscopic data / structure / reactivity / models}

Résumé - Développements en chimie des substances humiques aquatiques. Le travail scientifique dépend toujours de savoirs spécifiques déjà acquis. Ceci s'applique notamment au domaine de la chimie des substances aquatiques. Certaines étapes importantes ont été : (1) la standardisation des procédés d'isolement des substances humiques et avec elle la disponibilité de substances de référence ; (2) l'application des outils puissants de la spectroscopie RMN et de la spectrométrie de masse combinés à la pyrolyse pour identifier les blocs moléculaires constitutifs ; (3) l'application de la chromatographie sur gel avec détection multiple y compris la spectroscopie vibrationnelle et électronique et la mesure en ligne pour la caractérisation directe de la matière organique dans les échantillons aquatiques ; (4) l'application de la fluorescence statique et résolue en temps pour étudier les états excités et la formation de complexes ; (5) l'étude des réactions avec des partenaires bien définis et (6) le développement des modèles informatiques pour les structures moléculaires dont le niveau d'énergie est minimum.

procédé d'isolement / données de spectroscopie / structure / réactivité / modèle

Communicated by Isabelle Lamy

* Correspondence and reprints

fritz.frimmel@ciw.uni-karlsruhe.de 


\section{Introduction}

Humic matter is as old as life on earth. As a sink of organisms and a source for new living cells it plays a fundamental role in the environment. Already at the end of the 18th century, Achard [3] investigated peat and extracted soil with base. Berzelius [8] isolated humic substances from a Swedish spring. Only since about the beginning of the 20th century has the scientific interest for these substances emerged in a broad scale $[18,33,47$, 75]. It was the field of soil and agriculture which stimulated investigations of the structure, properties and function of the brownish heterogeneously composited organic material $[21,25,38,61,69,70,79]$.

Even though it was clear from the beginning that the water soluble part of the material was the most interesting one for reactions and transport phenomena, it was not until the second half of the century that systematic work began on aquatic humic matter $[36,51,68]$. Since then, it has become widely accepted that humic substances are ubiquitous in water [73], and a great interest in their chemical structure and role in aquatic systems has developed [22], including technical applications [71]. In 1983, the International Humic Substances Society (IHSS) was founded and members have collected data and results on refractory matter in soil and water $[5,13$, 17, 29, 65]. The term "refractory" commonly reflects a relatively low biodegradability, but it has not been defined properly. The number of publications on aquatic humic substances has increased significantly in recent years. It is the aim of this paper to give an overview on important milestones in aquatic humic chemistry, and on the consequences for scientific progress in this field.

\section{Definitions}

According to the complex structure of humic substances (HS) they can not be defined precisely. Based on fractionation procedures and on specific research views, operational definitions are often used. Some common terms are given in Table I.
Table I. Common terms used for humic substances and their fractions.

\begin{tabular}{cc}
\hline Abbreviation & Meaning \\
\hline AHS & Aquatic Humic Substances \\
DOM & Dissolved Organic Matter \\
FA & Fulvic Acids (acid and base soluble) \\
HA & Humic Acids (base soluble) \\
HS & Humic Substances \\
NHS & Non Humic Substances \\
NOM & Natural Organic Matter \\
ROM & Recalcitrant Organic Matter \\
ROS & Refractory Organic Substances \\
SOM & Soil Organic Matter \\
DOC & Dissolved Organic Carbon $(<0.45 \mu \mathrm{m})$ \\
TOC & Total Organic Carbon \\
POC & Particulate Organic Carbon \\
\hline
\end{tabular}

It is necessary to note that some of the terms are synonymous. Since most terms are operationally defined, they need a detailed description of the experimental procedure of their isolation, preparation and origin.

\section{Isolation methods}

The concentrations of organic carbon (OC) in aquatic systems range between $40 \mathrm{mg} \cdot \mathrm{L}^{-1}$ in brown water and soil seepage water and $0.5 \mathrm{mg} \cdot \mathrm{L}^{-1}$ typical for ground water and sea water [73]. These concentrations are too low for a direct application of most of the advanced analytical methods. In addition, matrix effects from high salt content or metal ions can lead to severe disturbances in structural investigations. Therefore isolation and concentration procedures are needed. The adsorption at low $\mathrm{pH}$-values $(\mathrm{pH} \leq 2)$ on synthetic resins like XAD 2 or XAD 8 followed by desorption at high $\mathrm{pH}$-values $(\mathrm{pH}>12)[48,56]$ turned out to be a useful method. The IHSS recommended standard procedures for preparative isolation of HS [72] and supplied reference materials [46]. The principle of the isolation method has been applied in many variations, leading to new operationally defined products and fractions $[1,6,45]$. A scheme for the fractionation into so called hydrophobic and hydrophilic materials is shown in Figure 1. 


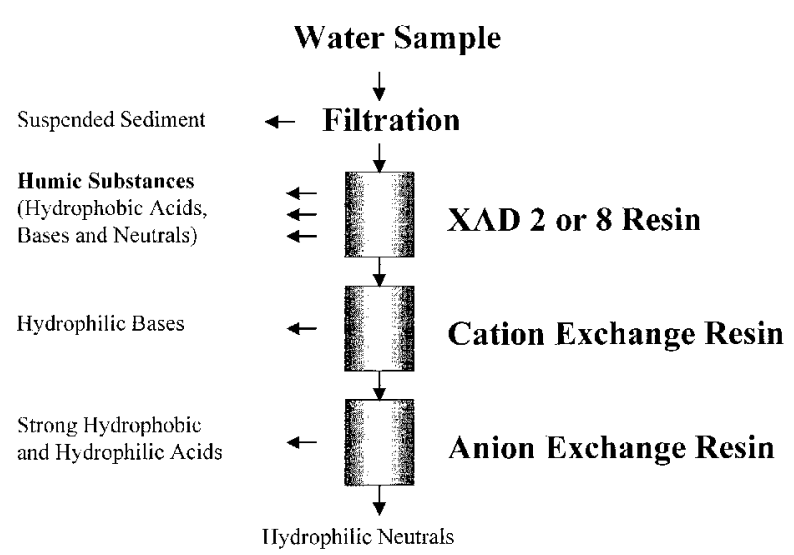

Figure 1. Isolation procedure for aquatic humic substances.

The standardized methods for the isolation of HS and the availability of reference samples have stimulated the investigation of the structure and character of the material and have lead to the intercalibration of analytical methods and by this to meaningful results. Even though there is no doubt about the merits of this approach, some pitfalls have to be kept in mind. The treatment of the water samples including high and low $\mathrm{pH}$-values may result in structural changes. Especially when oxygen is not excluded, oxidation reactions are very likely to occur. To our knowledge, however, there are no publications on a reliable comparison of extraction procedures under oxic and anoxic conditions. There are other fundamental questions: how good the obtained fractions represent the natural situation, and whether the eliminated other water constituents influence the typical character of HS or not. A way out of that dilemma seem to be proper mass balances, e.g. on the basis of $\mathrm{OC}$, and the development of sensitive methods which are suited for a direct application to the unchanged original aquatic samples. Other isolation and concentration methods like reverse osmosis or nanofiltration have also been introduced [1, 67].

\section{Vibrational and electronic spectroscopy}

The yellowish-brownish colour of HS is one of their typical properties [51]. The spectral absorption in the UV-range is even more pronounced.

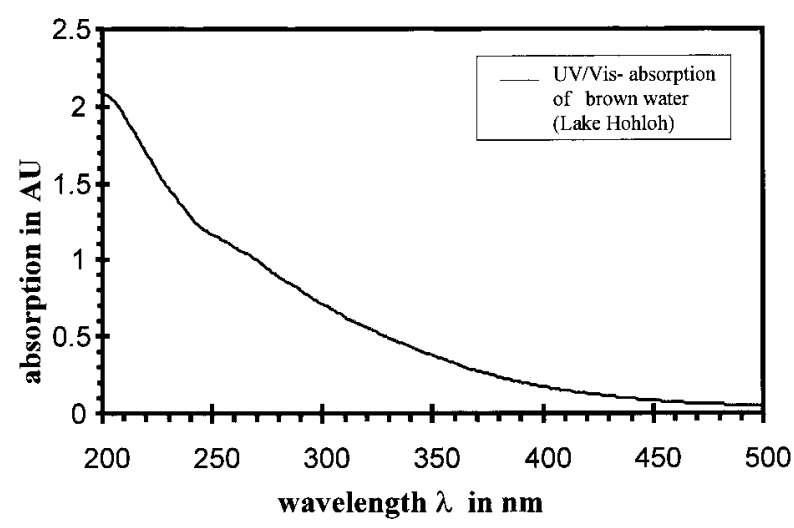

Figure 2. UV-vis spectrum of brown water.

Figure 2 shows a characteristic spectrum of a brown water. The absorbance decreases with increasing wavelength in a roughly exponential way and can be measured directly without any pretreatment of the water.

Even though the UV-vis spectra of HS are not too informative, they reflect the valence electrons and unsaturated character of the structural building blocks, especially if differential spectroscopy is used [39]. Related to the OC, the UV absorbance (e.g. specific UV absorbance SUVA at $1=254 \mathrm{~nm}$ ) can give a good estimation of the reactivity of the material against chlorine. This has become a valuable tool to predict the amount of by-product formation in the disinfection of drinking water.

Another specific property of HS is their fluorescence. This was shown by several researchers $[12$, 19, 66]. According to the Jablonski diagram, which is a simplified illustration of the processes taking place during absorption of radiation and relaxation, one way of obtaining information on the excited electronic states of a molecule is the recording of fluorescence spectra. Molecular differences can be most clearly seen in the synchronous mode [10]. Since complex formation of HS with paramagnetic metal ions and pollutants like polycyclic aromatic hydrocarbons (PAH) lead to a quenching of the original HS fluorescence, this can be used to learn about molecular interactions and electron donoracceptor complexes [7, 23, 58]. Due to the sensitivity of fluorescence spectroscopy these investigations again can be done directly in aquatic samples 


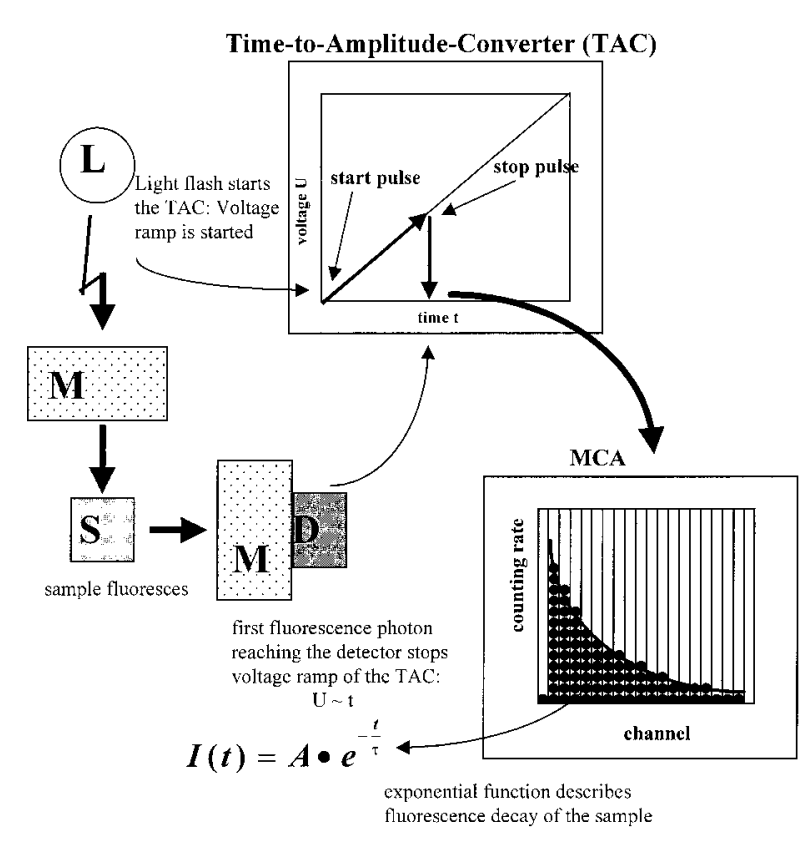

Figure 3. Principle of time-resolved fluorescence measurement of dissolved humic matter (flash lamp L; monochromator M; sample S; detector D).

at natural concentrations. By this, denaturing of HS and artifact formation are minimized.

Recently time-resolved fluorescence spectroscopy was applied to aquatic HS. The principle of the method is given in Figure 3. It can be shown that there are at least three excited states which decay in different time windows of the nanosecond range (Fig. 4) [41].

As expected, chemical reactions like complex formation and oxidation change the decay rates and the distribution of the components. With an increased number of investigated samples this will lead to a better understanding of the reactivity of HS even though their molecular structure still remains unknown.

\section{Solid sample investigation}

Freeze drying of aquatic samples or aqueous fractions of isolates leads to solid HS samples. The freeze drying procedure is one of the most gentle

\section{Stern-Volmer analysis}

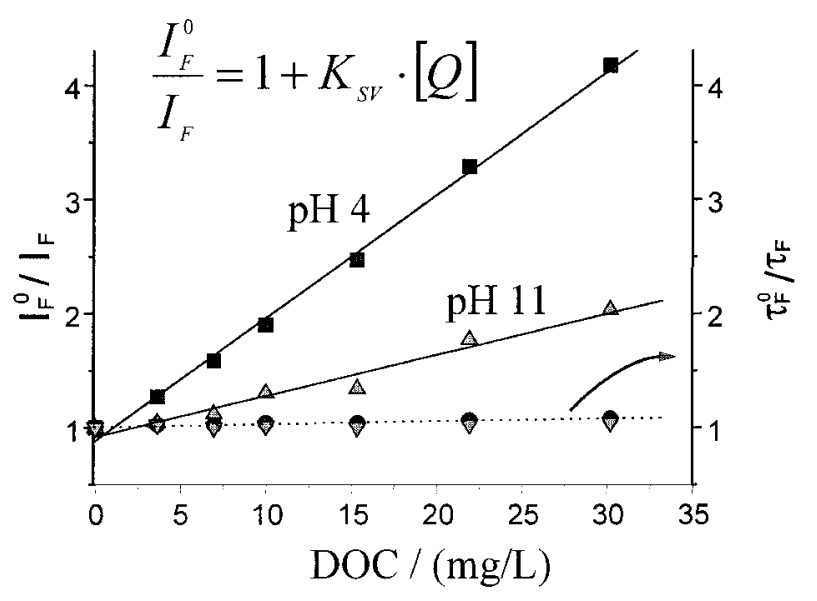

Figure 4. Multi-component analysis (MCA) for HS regions with different fluorescence decay rates.

methods for preparation, and opened the application of a number of powerful analytical tools like analytical pyrolysis (Py) coupled with mass spectrometry (MS) or gas chromatography/MS and solid state nuclear magnetic resonance (NMR). The application of those methods has led to information on building blocks and structural sub-units. However, the question remains open as to what extent the molecular structure revealed for the solid state is representative of the dissolved one.

\subsection{Analytical pyrolysis}

Oven pyrolysis in combination with field ionization mass spectrometry (FIMS) has turned out to be a useful tool for supplying ideas about possible building stones of HS in the range of up to a few hundred mass units. Especially, the high resolution mode for mass units gives reasonable suggestions for molecular structures including hetero-atoms of the pyrolysis product. A flexible temperature program and the temperature correlated product pattern open a wide field for macromolecular structure suggestions [62, 63]. A general scheme of PY-FIMS is given in Figure 5. Pitfalls come from a still poor understanding of the pyrolysis process and from uncertainties about the yield of the sample-specific products. A lack of oxygen in the products found 

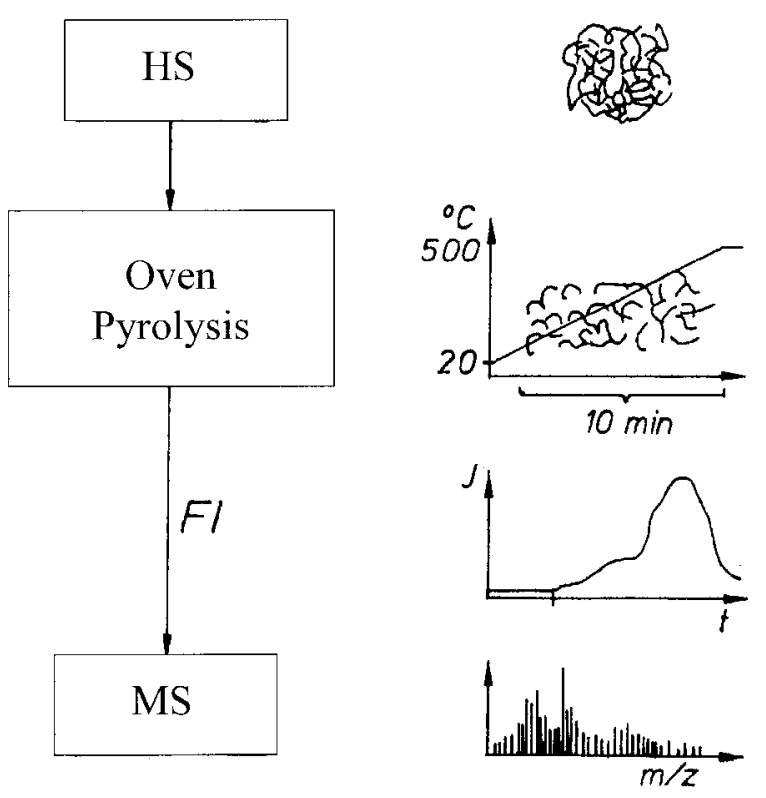

Figure 5. Application of pyrolysis FIMS for the investigation of aquatic HS.

compared with the amount shown by elemental analysis of the gross sample and an overestimation of aromatic structures are known problems.

Pyrolysis in combination with GC/MS is another method for the identification of molecular fragments. The volatilisation of parts of the macromolecules is normally done by Curie point pyrolysis which works in the millisecond-range. The products obtained (see Tab. II) are fractionated by gas chromatography and identified by MS $[2,9,59]$.

Table II. Examples for typical products identified after pyrolysis of aquatic HS.

\begin{tabular}{|c|c|}
\hline Class of compounds & Identified compounds \\
\hline alkenes & $\mathrm{C}_{4}-\mathrm{C}_{8}$ alkenes, $\mathrm{C}_{4}-\mathrm{C}_{8}$ alkadienes \\
\hline furans & $\begin{array}{l}\text { methylfuran, hydroxyfuran, } \\
\text { methylfurfural }\end{array}$ \\
\hline alkylbenzenes & $\begin{array}{l}\text { toluene, } \mathrm{C}_{2} \text {-alkylbenzene, } \\
\mathrm{C}_{6} \text {-alkylbenzene }\end{array}$ \\
\hline alkylphenols & $\begin{array}{l}\text { cresol, xylenol, } \\
\text { methoxyvinylphenol }\end{array}$ \\
\hline dihydroxybenzenes & $\begin{array}{l}\text { dihydroxybenzene, } \\
\text { dihydroxymethylbenzene }\end{array}$ \\
\hline $\begin{array}{l}\text { methoxyphenols, } \\
\text { dimethoxyphenols }\end{array}$ & $\begin{array}{l}\text { 2,6-dimethoxyphenol, } \\
\text { coniferyl alcohol, } \\
\text { 2,6-dimethoxy-propenyl-phenol, } \\
\text { sinapyl alcohol }\end{array}$ \\
\hline
\end{tabular}

\subsection{NMR-spectroscopy}

Nuclear magnetic resonance methods belong to the nondegradative analytical procedures and have been applied successfully for the characterization of complex samples and macromolecules [77]. The necessary masses and concentrations of samples have decreased significantly over the last few years, but are still far from original aquatic samples. Besides ${ }^{1} \mathrm{H}$ and ${ }^{13} \mathrm{C}$ heteroatomes [27, 28, 43, 77], especially ${ }^{15} \mathrm{~N}$ and ${ }^{31} \mathrm{P}[50,54]$ have been investigated. Dissolved samples and solid state material were used.

In solid state NMR, magic angle spinning (MAS) and cross polarization (CP) have significantly improved the results obtained for HS samples [44]. Recently, the distribution and molecular form of heteroatoms have been visualized by two dimensional modes [31], and derivatisation reactions like silylation in combination with NMR have led to information on structure reactivity relations [30]. This makes the NMR technique one of the most informative methods for the characterization of the composition of HS.

The relative amount of carbon assigned to structural areas and functional groups in brown water FA are given in Table III.

The NMR-data are well suited for correlation with the results from other analytical methods, and as a consequence for intercalibration and quality control of analytical determinations.

Table III. Relative amounts of differently assigned $\mathrm{C}$ of HO13 FA as revealed by ${ }^{13} \mathrm{C}-\mathrm{CPMAS}-\mathrm{NMR}$ [51].

\begin{tabular}{ccc}
\hline Functionality & Chemical Shift & $\%$ of C \\
\hline Aliphatic & $0-50 \mathrm{ppm}$ & 22 \\
Overlap Region & $50-60 \mathrm{ppm}$ & 5 \\
O-Allyl-C & $60-100 \mathrm{ppm}$ & 21 \\
Aromatic & & \\
Unsubstituted & $100-140 \mathrm{ppm}$ & 25 \\
O, N-Substituted & $140-160 \mathrm{ppm}$ & $10-12$ \\
Carboxyl & $160-190 \mathrm{ppm}$ & $12-14$ \\
Carbonyl & $190-220 \mathrm{ppm}$ & 3 \\
\hline
\end{tabular}




\section{Molecular size estimation}

Among the principles for determination of molecular sizes or masses, gel permeation is an attractive method. With powerful detection systems it can be applied to original aquatic samples. Keeping in mind the limitation of interpretation due to undefined sorption effects and the lack of authentic calibration substances, the method is especially suited for comparative studies. In former years the most common stationary phase was Sephadex, and only UV detectors provided a satisfactory power for the direct investigation of aquatic samples [24]. In recent years, TSK columns with higher resolution have become available. TSK-gels of the HW and PW type are hydrophilic copolymers made from ethylene glycol and methacrylate [74]. Furthermore, a sensitive detection system for organic carbon was developed. This system can quantify fractions representing a few $\mu \mathrm{g} \cdot \mathrm{L}^{-1} \mathrm{OC}$ and by this is well suited for exact mass balances. Figure 6 shows the scheme of the chromatographic column and the UV/vis-detector followed by the OC detection system. It contains a thin-film UVreactor which after the exclusion of the inorganic carbonate species oxidises the organic substances to $\mathrm{CO}_{2}$ which is quantified in a non-dispersive IRdetector. UV leach reactors are used for the produc- tion of a low carbon water as a mobile phase [34]. The system works with original water samples of a volume up to $2 \mathrm{~mL}$.

A typical gel chromatogram of a brown water is given in Figure 7. It shows the high molecular mass fraction assigned to HS at short retention time $\left(t_{R}\right)$ followed by small mono- and diprotic acids. At higher $t_{R}$, hydrophobic smaller molecules appear.

There have been several authors adressing the errors involved in deriving molecular weight data for HS from gel chromatography. Perminova et al. [53] suggested a method which uses the additional structural data of HS to obtain more reliable molecular weight numbers for HS. Besides its suitability for weight estimation, gel chromatography is well suited for a general characterization of the DOC of aquatic systems and for the comparison of NOM from different sources [32]. The running conditions guarantee minimized influences on the identity of the samples.

\section{Reactions and interactions}

Due to the complex composition of HS it is highly questionable whether the identification of the molecular structure in the classical sense of analytical

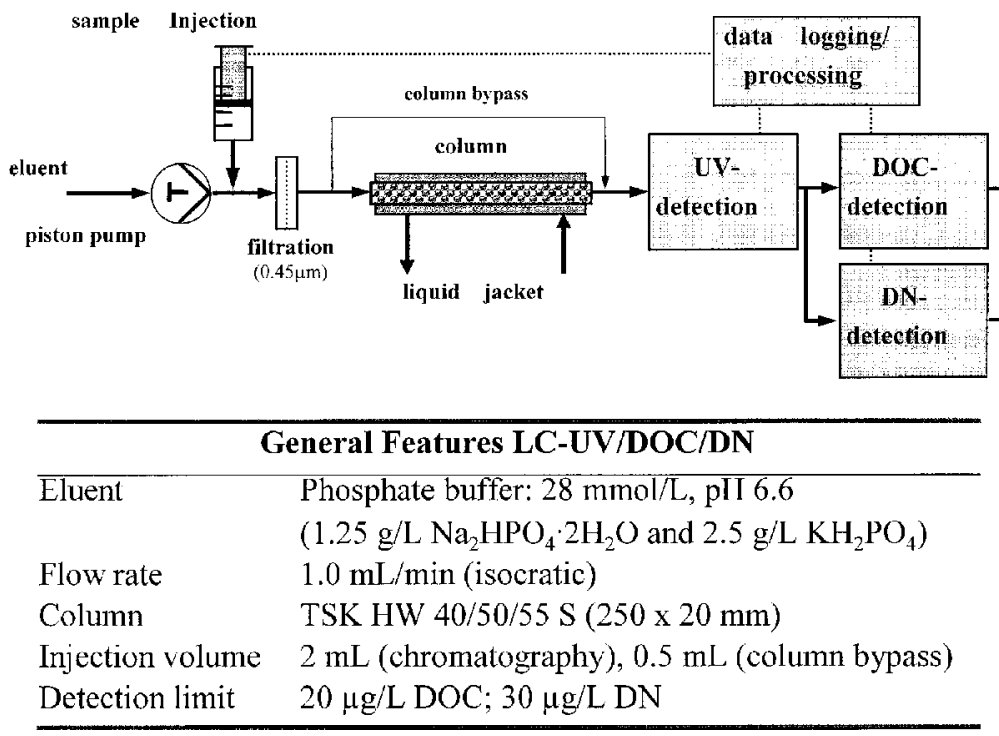

Figure 6. Gelchromatography system with UV- and DOC-detection for the characterization of HS. 


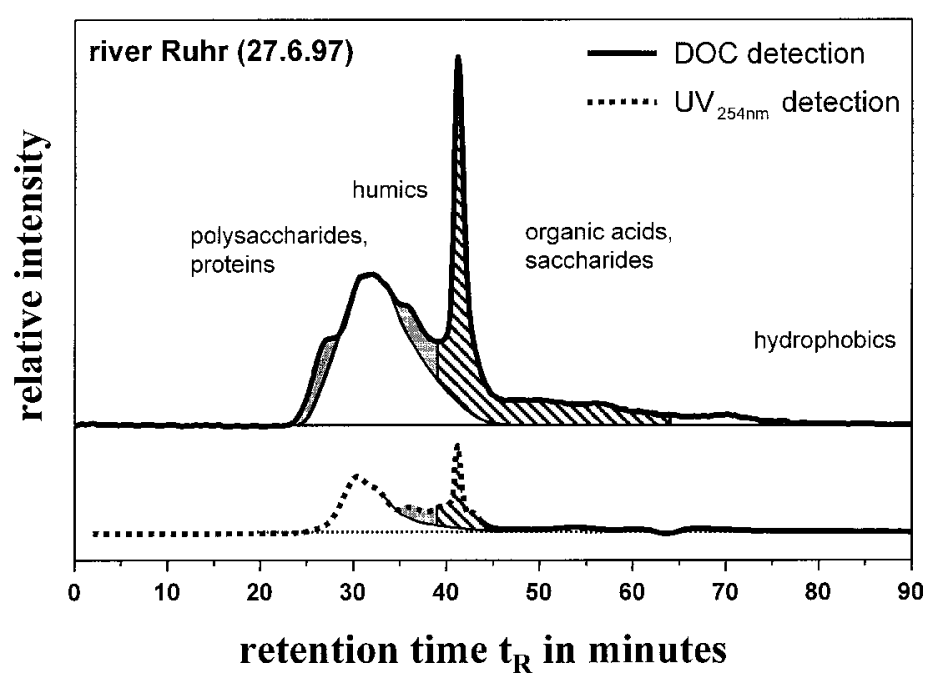

Figure 7. Gelchromatogram with OC detection of aquatic NOM. chemistry will be ever achieved. A feasible method for obtaining information on the structure related reactivity is to react HS under well defined conditions with well defined substances to well defined products. This approach matches also the needs of a row of technical applications which are strongly influenced by HS.

\subsection{Formation of AOX and THM and other disinfection by-products}

Since the discovery of trihalomethanes (THM) as disinfection by-products in the chlorination of HScontaining water by Rook [57], the reactions of HS with chlorine and bromine have become a major health concern [35]. A model for the reaction of HS with chlorine was developed (Fig. 8), and far more than 150 reaction products have been identified [55]. Some compounds turned out to be mutagenic. The mutagenicity of MX and EMX (Fig. 9) was investigated by Kronberg [40].

\subsection{Metal complexation}

HS can act as electron- (e)-donor. In the presence of metals as e-acceptor, complexes are formed. The complex formation can be quantified by measuring the fluorescence intensity. According to the hypothesis that HS only fluoresce as uncomplexed ligand and that complexes with paramagnetic metal ions show no fluorescence, stability constants can be calculated [76]. The investigation of systematically varied donor/acceptor ratios can be used for a SternVolmer plot (Fig. 10). From the Stern-Volmer relation it can be seen that the complex formation is a static process which fixes the metal ions to specific ligand functional sizes. It is also interesting to see that $\mathrm{Al}(\mathrm{III})$ as a diamagnetic metal ion does not quench the fluorescence of the ligand. For most metal ions the experiments can be done in a concentration range typical for aquatic systems.

\subsection{Interactions with xenobiotics}

The structure of HS combines hydrophobic and hydrophilic regions. The resulting ambivalent character is the reason for solubility enhancement of lipohilic xenobiotics in water. Chiou et al. [11] showed that NOM from different origins have a different influence on the apparent solubility of DDT. Isolated HAs caused a stronger effect than river water and isolated FAs.

The interaction of HS with pyrene was investigated by Kumke et al. [42]. There was a clear visible effect when the fluorescence of the PAH was decreased in the presence of HS (Fig. 11). The interaction gained strength at lower $\mathrm{pH}$-values. 
<smiles>[R]c1c(O)cc(O)c([R3])c1[13CH3]</smiles><smiles>[R]C1C([R])[C@]2(O[C@@H]2O)C(Cl)(Cl)C(=O)C1([R3])Cl</smiles>

$\underline{\mathrm{HOCl}}$

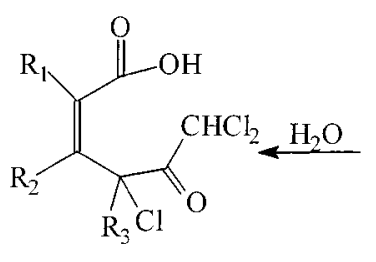<smiles>[R]C(=O)C(CC)C([R3])(Cl)C(=O)C(Cl)(Cl)OCC</smiles>

AOX

Numerous articles on the direct and indirect photolysis of xenobiotics mediated by humic substances have been published, for example by Aguer et al. [4], Mills and Sullivan [49], Fischer et al. [20], and Cooper et al. [15].

\subsection{Structural models}

Chemists think in terms of molecules. This brought some active groups to the attempt to draw detailed molecular structures for humic matter [14, 16, 26, 37, 60]. Most of the models have been developed from the specific view of the investigation and by this reflect only specific properties of the matter. Some confusion arose from over-interpretations of these structures which should be seen
Figure 8. Formation of AOX and THM as products of the reaction between HS and $\mathrm{HOCl}$.

as models giving not more than a possible suggestion and a reasonable explanation for measured properties of the samples. The operational definition of HS, their complex constitution and the manifold isomeric and energetically equivalent possibilities of structural arrangements make it highly unlikely that molecules of the given structures ever existed in humic material. As a consequence, models have been developed which do not use a detailed molecular structure but instead use symbols for building stones building blocks and functional regions within humic substances $[52,79]$. Despite the confusion which arose from the misunderstanding of molecular structure models the positive aspect of the attempt to present measured data in a transparent form remains.<smiles></smiles>

$\mathrm{MX}$, ring form<smiles>C#CCCCC(C=O)=C(Cl)C(=O)O</smiles>

MX, open form<smiles>C#CC=CC(C=O)=C(Cl)C(=O)O</smiles>

EMX
Figure 9. Structure of MX and EMX. 


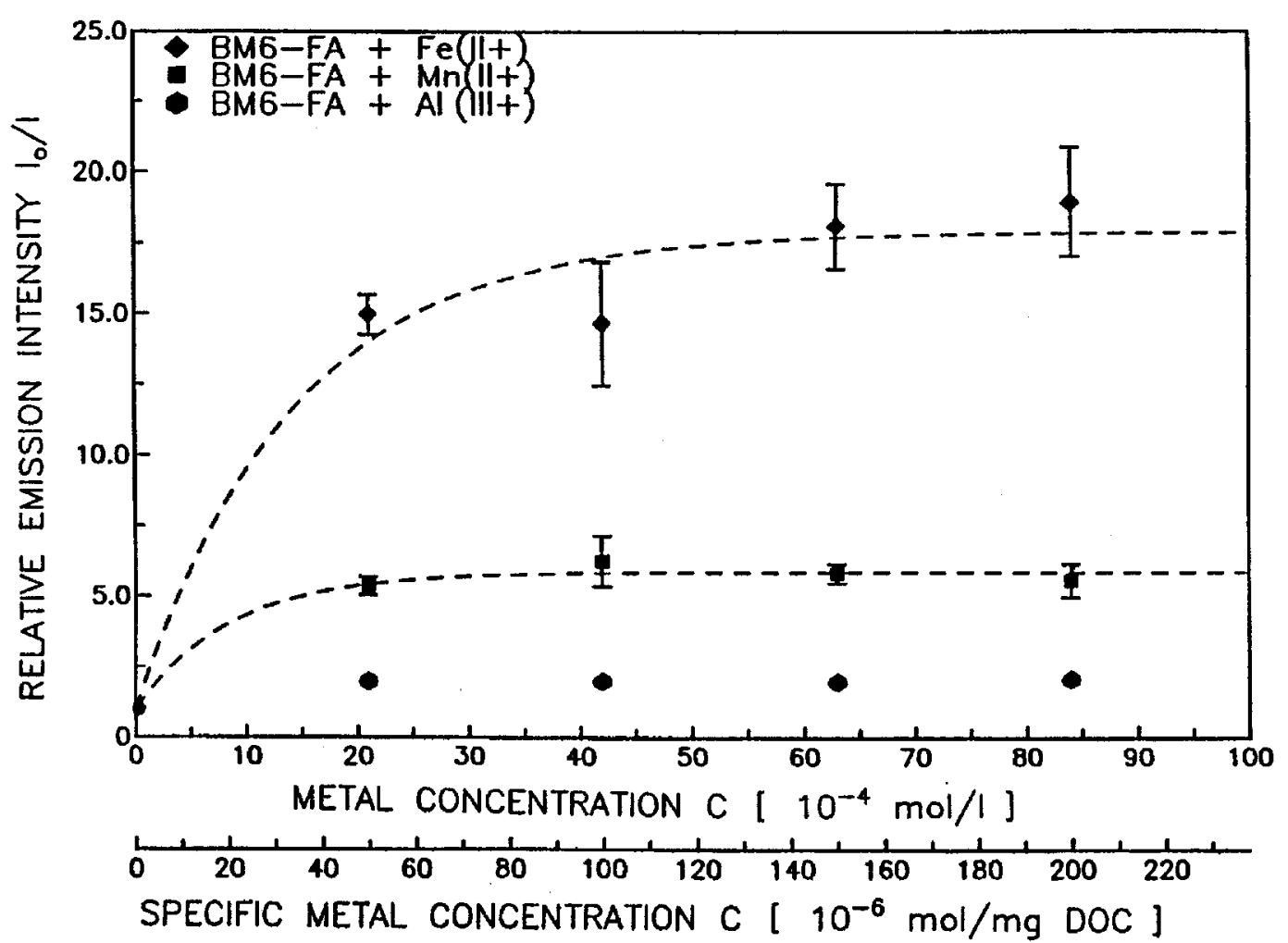

Figure 10. Stern-Volmer plot for the complexation of aquatic HS with metal ions.

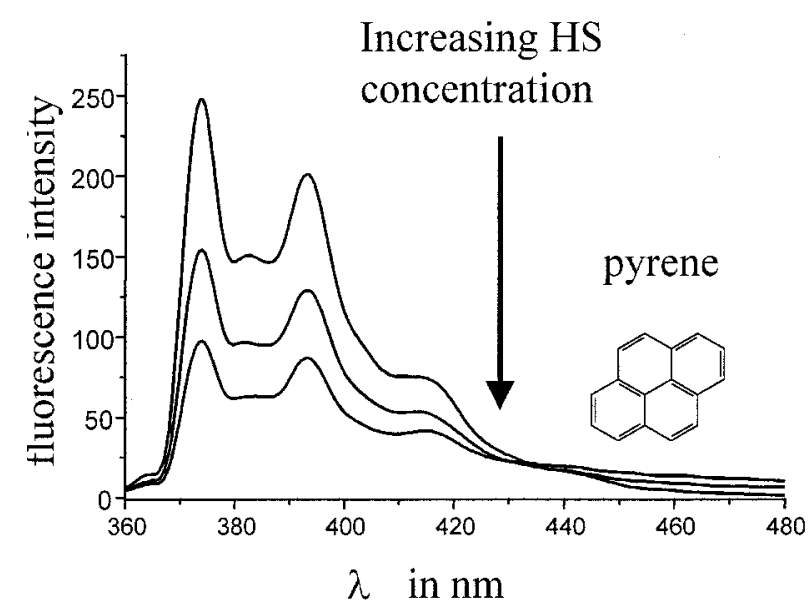

Figure 11. Characterization of the interactions between HS and pyrene (according to [64]).
Recently a molecular structure has been proposed on the basis of force field calculations of lowest energy structures [64]. The availability of powerful data systems and programs for molecular calculations in connection with carefully measured data on well defined samples can give new impulse to the understanding of structure property relations in HS.

\section{Where to go}

The understanding of the function of ROS in nature is of fundamental importance. The water soluble part of it (DOM) plays a key role in this respect, for it is involved in the major reactions and transport processes. Further work should focus on:

1. Analytical multimethod characterization of typical samples from different origins to give a 
comprehensive image of the molecular building blocks of the DOM;

2. Structure and physico-chemical property relations to understand dynamic processes in ecosystems;

3. Biochemical interaction of DOM with cells and enzymes to learn about genesis and the fate of ROS; this includes the colloidal range;

4. Formation and stability of ROS-bound xenobiotics including changed toxicity;

5. Environmental influences on the production and character of DOM.

Most of these topics need interdisciplinary approaches and new views. This may become obvious from such questions as what "dissolved" means, and how can we explain "refractory". Operational definitions may help at the first stage, but molecular size distributions and lifetimes will have to follow.

Acknowledgements: Part of the work was funded by Deutsche Forschungsgemeinschaft, (DFG, Schwerpunktprogramm ROSIG). Prof. Dr. Lüdemann supplied unpublished data, and Dr. Abbt-Braun and Margit Müller helped in composing the article. Their help is highly acknowledged.

\section{References}

[1] Abbt-Braun G., Frimmel F.H., Lipp P., Isolation of organic substances from aquatic and terrestrial systems - Comparison of some methods, Z. WasserAbwasser. Forsch. 24 (1991) 285-292.

[2] Abbt-Braun G., Frimmel F.H. Schulten H.-R., Structural Investigations of Aquatic Humic Substances by Pyrolysis-Field Ionization Mass Spectrometry and Pyrolysis-Gas Chromatography/Mass Spectrometry, Water Res. 23 (1989) 1579-1591.

[3] Achard F.K., Chemische Untersuchung des Torfs, Crell's Chem. Ann. 2 (1786) 391-403.

[4] Aguer J.P. et al., Comparison of the Photoinductive Properties of Commercial, Synthetic and Soil-extracted Humic Substances, J. Photochem. Photobiol. A 103 (1997) 163-168.

[5] Aiken G.R., McKnight D., Wershaw R.L., MacCarthy P. (Eds.), Humic Substances in Soil, Sediment and Water, John Wiley \& Sons, New York, 1985.
[6] Aiken G.R., Thurman E.M., Malcolm R.L., Walton H.F., Comparison of XAD macroporous resins for the concentration of fulvic acid from aqueous solution, Anal. Chem. 51 (1979) 1799-1803.

[7] Bartoli F. et al., Fluorescent and Colloidal Properties of an Organic Solution from Podzol During the Copper Complexation Process, Soil Biol. Biochem. 19 (1987) 355-362.

[8] Berzelius J.J., Afhandlingar i Physik, Kemi, och Mineralogie 1 (1806) 124-145.

[9] Bracewell J.M., Robertson G.W., Characteristics of soil organic matter in temperate soils by Curie point pyrolysis-mass spectrometry, J. Soil Sci. 35 (1984) 549-558.

[10] Cabaniss S.E., Shuman M.S., Synchronous fluorescence spectra of natural waters: Tracing sources of dissolved organic matter, Mar. Chem. 21 (1987) 37-50.

[11] Chiou C.T., Malcolm R.L., Brinton T.I., Kile D.E., Water solubility enhancement of some organic pollutants and pesticides by dissolved humic and fulvic acids, Environ. Sci. Technol. 29 (1986) 502-508.

[12] Christman R.F., Ghassemi M., Chemical Nature of Organic Color in Water, J. Am. Water Works Assoc. 58 (1966) 723-741.

[13] Christman R.F., Gjessing E.T. (Eds.), Aquatic and Terrestrial Humic Materials, Ann Arbor Science Publishers, Ann Arbor, 1983.

[14] Christman R.F., Norwood D.L., Seo Y., Frimmel F.H., Oxidative degradation of humic substances from freshwater environments, in: Hayes M.H.B., MacCarthy P., Malcolm R.L., Swift R.S. (Eds.), Humic Substances II: In Search of Structure, John Wiley \& Sons, New York, 1989, pp. 33-68.

[15] Cooper W.J. et al., Sunlight-induced Photochemistry of Humic Substances in Natural Waters: Major Reactive Species, in: Suffet I.H., MacCarthy P. (Eds.), Aquatic Humic Substances. Influence on Fate and Treatment of Pollutants, American Chemical Society, Washington DC, 1989, pp. 333-362.

[16] Dragunov C.C., Zhelokhovtseva H.H., Strelkova E.J., A comparative study of soil and peat humic acids, Pochvovedenie 7 (1948) 409-420 [in Russian].

[17] Drozd J., Gonet S.S., Senesi N., Weber J. (Eds.), The Role of Humic Substances in the Ecosystems and in Environmental Protection. PTSH - The Polish Society of Humic Substances, Wroclaw, 1996.

[18] Eller W., Künstliche und natürliche Huminsäuren, Brennstoffchem. 2 (1921) 129-133. 
[19] Ewald M. et al., Corrected Fluorescence Spectra of Fulvic Acids Isolated from Soil and Water, Environ. Sci. Technol. 17 (1983) 501-504.

[20] Fischer A.M. et al., Primary Photochemical Processes in Photolysis Mediated by Humic Substances, in: Zika R.G., Cooper W.J. (Eds.), Photochemistry of Environmental Aquatic Systems, ACS Symposium Series 327, American Chemical Society, Washington, DC, 1987, pp. 141-156.

[21] Flaig W., Chemische Untersuchungen an Huminstoffen, Z. Chem. 4 (1964) 253-265.

[22] Frimmel F.H., Christman R.F., Humic Substances and Their Role in the Environment, John Wiley Interscience, Berlin, 1988.

[23] Gauthier D.R., Shane E.C., Guerin W.F., Seitz W.R., Grant C.L., Fluorescence quenching method for determining equilibrium constants for PAH binding to dissolved humic materials, Environ. Sci. Technol. 20 (1986) 1162-1166.

[24] Gjessing E., Physical and Chemical Characteristics of Aquatic Humus, Ann Arbor Science Publishers Inc., Ann Arbor, 1976.

[25] Haider K., Martin J.P., Synthesis and transformation of phenolic compounds by Epicoccum nigrum in relation to humic acid formation, Soil Sci. Am. Proc. 31 (1967) 766-772.

[26] Harvey G.R., Boran D.A., Geochemistry of humic substances in seawater, in: Aiken G.R., McKnight D.M., Weshaw R.L., MacCarthy P. (Eds.), Humic Substances in Soil, Sediment and Water, John Wiley \& Sons, New York, 1985, pp. 233-247.

[27] Hatcher P.G., Rowan R., Mattingly M.A., ${ }^{1} \mathrm{H}$ and ${ }^{13} \mathrm{CNMR}$ of marine humic acids, Organ. Geochem. 2 (1980) 77-85.

[28] Hatcher P.G., Spiker E.C., Szeverenyi N.M., Maciel G.E., Selective preservation and origin of petroleum-forming aquatic kerogen, Nature 305 (1983) 498-501.

[29] Hayes M.H.B., MacCarthy P., Malcolm R.L., Swift R.S. (Eds.), Humic Substances II - In Search of Structure, John Wiley \& Sons, Chichester, 1989.

[30] Hertkorn N., Günzl A., Perdue M.E., Schmitt Ph., Freitag D., NMR Investigations of Humic Substances, in: Frimmel F.H., Abbt-Braun G. (Eds.), ROSE 1 Abstracts of Oral and Poster Papers. Heft 35 der Veröffentlichungen des Lehrstuhls für Wasserchemie und der DVGW-Forschungsstelle am Engler-BunteInstitut der Universität Karlsruhe, Karlsruhe, 1997, pp. 19-21.
[31] Herzog H., Haiber S., Burba P., Buddrus J., Quantification of Partial Structures of Aquatic Humic Substances by ${ }^{1} \mathrm{H}-\mathrm{NMR}$ under WATR Conditions, Fresenius J. Anal. Chem. 359 (1997) 167-170.

[32] Hesse S., Frimmel F.H., Biochemical Characterization of Refractory Organic Substances, Acta Hydrochim. Hydrobiol. 27 (1999) 94-97.

[33] Hoppe-Seyler F., Über Huminsubstanzen, ihre Entstehung und ihre Eigenschaften, Hoppe-Seylers, Z. Physiol. Chem. 13 (1889) 66-122.

[34] Huber S.A., Frimmel F.H., A New Method for the Characterization of Organic Carbon in Aquatic Systems, Int. J. Environ. Anal. Chem. 49 (1992) 49-57.

[35] Jolley R.L., Bull R.J., Davis W.P., Katz S., Roberts M.H. Jr., Jacoby V.A., Water Chlorination: Chemistry, Environmental Impact and Health Effects, Vol. f5, Lewis Publishers Inc., Chelsea, MI, 1985.

[36] Kalle K., The problem of Gelbstoff in the sea, Oceanogr. Mar. Biol. Annu. Rev. 4 (1966) 91-104.

[37] Kleinhempel D., Ein Beitrag zur Theorie des Huminstoffzustandes, Albrecht Thear Arch. 14 (1970) 3-14.

[38] Kononova M.M., Soil Organic Matter: Its Nature, Its Role in Soil Fertility, 2nd ed., Pergamon, Oxford, 1966.

[39] Korshin G.V. et al., Section 1: Problem Identification - Overviews - Use of Differential Spectroscopy to Evaluate the Structure and Reactivity of Humics, Water Sci. Technol. 40 (1999) 9-16.

[40] Kronberg L., Identification and Quantification of the Ames Mutagenic Compound 3-Chloro-4(dichloromethyl)-5-hydroxy-2(5H)-furanone and of Its Geometric Isomer (E)-2-Chloro-3-(dichloromethyl)-4oxobutenoic Acid in Chlorine-Treated Humic Water and Drinking Water Extracts, Environ. Sci. Technol. 31 (1988) 1033-1039.

[41] Kumke M.U., Abbt-Braun F., Frimmel F.H., Time-resolved fluorescence measurements of aquatic natural organic matter (NOM), Acta Hydrochim. Hydrobiol. 26 (1998) 73-81.

[42] Kumke M.U., Löhmannsröben H.-G., Roch Th., Fluorescence quenching of polycyclic aromatic compounds by humic acid, Analyst 119 (1994) 997-1001.

[43] Lambert J., Buddrus J., Quantification of Isolated Methyl Groups in Aquatic Humic Substances by means of ${ }^{1} \mathrm{H}$ - and ${ }^{13} \mathrm{C}$-NMR Spectroscopy, Magnetic Reson. Chem. 34 (1996) 276-282. 
[44] Lankes U., Lüdemann H.-D., unpublished data obtained during the DFG-sponsored Research Program "Refraktäre Organische Säuren in Gewässern (ROSIG)", 1997.

[45] Leenheer J.A., Noyes T.I., A filtration and column adsorbent system for consite concentration and fractionation of organic substances from large volumes of water, U.S. Geological Survey Water Supply Paper No. 2230, U.S. Government Printing Office, Washington DC, 1984.

[46] MacCarthy P., A proposal to establish a reference collection of humic materials for interlaboratory comparisons, Geoderma 16 (1976) 179-181.

[47] Maillard L.C., Formation de matières humiques par action de polypeptides sur des sucres, C. R. Acad. Sci. 156 (1913) 148-149.

[48] Mantoura R.F.C., Riley J.P., The analytical concentration of humic substances from natural waters, Analyt. Chim. Acta 76 (1975) 97-106.

[49] Mills G.L., Sullivan L.R., Indirect Photolysis of Tetraphenylborate Sensitized by Humic Acid, Chemosphere 31 (1995) 4541-4547.

[50] Newman R.H., Tate K.R., Soil phosphorous characterisation by ${ }^{31} \mathrm{P}$ nuclear magnetic resonance, Commun. Soil Sci. Plant. Anal. (1980) 835-842.

[51] Packham R.F., Studies of organic colour in natural water, Proc. Soc. Water Treat. Exam. 13 (1964) 316-334.

[52] Pauli F.W., Soil Fertility, Adam Hilger, London, 1967.

[53] Perminova I.V., Frimmel F.H., Kovalevskii D.V., Abbt-Braun G., Kudryavtsev A.V., Hesse S., Development of predictive model for calculation of molecular weight of humic substances, Water Res. 2 (1998) 872-881.

[54] Preston C.M., Rauthan B.S., Rodger C.A., Ripmeester J.A., A hydrogen-1, carbon-13, and nitrogen-15 nuclear magnetic resonance study of r-benzoquinone polymers incorporating amino nitrogen compounds ("synthetic humic acids"), Soil Sci. 234 (1982) 277-293.

[55] Richardson S.D., Drinking Water Disinfection Byproducts, in: Meyers R.A. (Ed.), the Encyclopedia of Environmental Analysis and Remediation, Vol. 3, Wiley, New York, 1998, pp. 1398-1421.

[56] Riley J.P., Taylor D., The analytical concentration of traces of dissolved organic materials from seawater with Amberlite XAD-1, Analyt. Chim. Acta 46 (1969) 307-309.
[57] Rook J.J., Formation of haloforms during chlorination of natural waters, Water Treat. Exam. 23 (1974) 234-243.

[58] Saar R.A., Weber J.H., Fulvic acid: modifier of metal-ion chemistry, Environ. Sci. Technol. 16 (1982) 510A-517A.

[59] Saiz-Jimenez C., de Leeuw J.W., Chemical characterization of soil organic matter fractions by analytical pyrolysis-gas chromatography - mass spectrometry, J. Anal. Appl. Pyrol. 9 (1986) 99-119.

[60] Schnitzer M., Humic Substances in the Environment, Marcel Dekker, New York, 1972.

[61] Schnitzer M., Khan S.U., Humic Substances in the Environment, Marcel Dekker, New York, 1972.

[62] Schulten H.R., Abbt-Braun G., Frimmel F.H., Time-resolved pyrolysis field ionization mass spectrometry of humic materials isolated from freshwater, Environ. Sci. Technol. 21 (1987) 349-357.

[63] Schulten H.-R., Gleixner G., Analytical Pyrolysis of Humic Substances and Dissolved Organic Matter in Aquatic Systems: Structure and Origin, Water Res. 33 (1999) 2489-2498.

[64] Sein L.T. Jr., Varnum J.M., Jansen S.A., Conformational modeling of a new building block of humic acid: approach to the lowest energy conformer, Environ. Sci. Technol. 33 (1999) 546-552.

[65] Senesi N., Miano T.M., Humic Substances in the Global Environment and Implications on Human Health, Elsevier Science B.V., Amsterdam, 1994.

[66] Senesi N., Molecular and quantitative aspects of the chemistry of fulvic acid and its interaction with metal ions and organic chemicals. II. The fluorescence spectroscopy approach, Anal. Chim. Acta 232 (1990) 77-106.

[67] Serkiz S.M., Perdue E.M., Isolation of dissolved organic matter from Suwannee River using reverse osmosis, Water Res. 24 (1990) 911-916.

[68] Shapiro J., Chemical and biological studies on the yellow organic acids of lake water, Limnol. Oceanogr. 2 (1957) 161-179.

[69] Sposito G., Sorption of trace metals by humic materials in soils and natural waters, C.R.C. Crit. Rev. Environ. Control 16 (1986) 193-229.

[70] Stevenson F.J., Humus Chemistry, John Wiley Interscience, New York, 1982. 
[71] Suffet I.H., MacCarthy P., Aquatic Humic Substances - Influence on Fate and Treatment of Pollutants, American Chemical Society, Washington DC, 1989.

[72] Thurman E., Malcolm R.L., Preparative isolation of aquatic humic substances, Environ. Sci. Technol. 15 (1981) 463-466.

[73] Thurman E., Organic Geochemistry of Natural Waters, Martinus Nyhoff, Dordrecht, 1985.

[74] Toso Haas Catalogue, 1999.

[75] Waksman S.A., Humus, Williams and Wilkins, Baltimore, 1932.

[76] Weber J.H., Binding and Transport of Metals by Humic Materials, in: Frimmel F.H., Christman R.F.
(Eds.), Humic Substances and Their Role in the Environment, John Wiley \& Sons, Chichester, 1988, pp. $165-178$.

[77] Wilson M.A., Barron P.F., Gillman A.H., The structure of freshwater humic substances as revealed by ${ }^{13}$ CNMR spectroscopy, Geochim. Cosmochim. Acta 45 (1981) 1743-1750.

[78] Wilson M.A., NMR Techniques and Applications in Geochemistry and Soil Chemistry, Pergamon, Oxford, 1987.

[79] Ziechmann W., Huminstoffe, Verlag Chemie, Weinheim, 1980. 